\title{
Location Decisions of Foreign Banks and Competitive Advantage
}

\author{
Stijn Claessens and Neeltje Van Horen ${ }^{*}$
}

\begin{abstract}
While institutional differences have been found to affect country growth patterns, much has remained unexplained, including how economic actors "overcome" institutional weaknesses and how internationalization helps or hinders development. Banking is an institutionally-intensive activity and the location decision of foreign banks provides a good test of how institutional differences are dealt with. Specifically, we examine whether banks seek out those markets where institutional familiarity provides them with a competitive advantage over other foreign competitor banks. Using bilateral data on banking sector FDI in all developing countries and controlling for other factors, we find that competitive advantage is important in driving foreign banks' location decisions. The findings suggest that high institutional quality is not necessarily a prerequisite to be able to attract foreign direct investment in banking and that there are specific benefits, as well as risks, to international financial integration between developing countries.
\end{abstract}

JEL Classification Codes: F21, F23, G21

Keywords: foreign direct investment, international banking, institutions

\section{World Bank Policy Research Working Paper 4113, January 2007}

The Policy Research Working Paper Series disseminates the findings of work in progress to encourage the exchange of ideas about development issues. An objective of the series is to get the findings out quickly, even if the presentations are less than fully polished. The papers carry the names of the authors and should be cited accordingly. The findings, interpretations, and conclusions expressed in this paper are entirely those of the authors. They do not necessarily represent the view of the World Bank, its Executive Directors, or the countries they represent. Policy Research Working Papers are available online at http://econ.worldbank.org.

\footnotetext{
* Claessens is with the World Bank, University of Amsterdam and CEPR, and Van Horen is with the World Bank and the University of Amsterdam. We are grateful to Allaeddin Twebti, Siret Dinc, Matias Gutierrez and Haocong Ren for their help with collecting the data. Financial support for this project by United Kingdom's Department for International Development received through DECRG trade and services project is gratefully acknowledged. Email addresses: sclaessens@worldbank.org and nvanhoren@worldbank.org.
} 


\section{Introduction}

The last decade has seen many foreign banks entering other markets, especially in developing countries. This has been driven by globalization and increased financial integration. As for other foreign investment entry decisions, individual banks have to weigh the costs and risks to enter foreign markets against the opportunities at home and against other modalities to provide financial services across borders, such as through cross-border lending. Furthermore, foreign banks have many markets to choose from when entering to provide a broad range of financial services. This leads to the questions about what factors affect the decision of a bank to go abroad and enter a specific country. In the literature several factors have been identified.

Traditionally the internationalization of banks has been closely tied to the internationalization of non-financial firms; in other words, banks follow their customers to provide them with financial services abroad and thereby increase their business. Some studies have indeed shown that foreign direct investment in banking is correlated with the degree of bilateral trade and FDI between the source and the host country (Grosse and Goldberg, 1991, Brealey and Kaplanis, 1996, Williams, 1998, and Yamori, 1998). However, the provision of trade-related finance has tended to become less important. Instead, banks are increasingly providing non-trade-related financial services across borders, without needing to establish affiliates in foreign markets. Furthermore, firms can increasingly obtain trade finance from local banks.

Banks engage in foreign entry presumably also to increase the bank's profitability, within an acceptable risk profile and risk diversification goals. Indeed, host and source country characteristics related to profitability and risks have been found to be important drivers of banks' decision to penetrate a foreign market. Focarelli and Pozzolo (2000), for example, find that banks prefer to have subsidiaries in countries where expected profits are larger, because of higher expected economic growth and the prospect of benefiting from local banks’ inefficiencies. And Galindo, Micco, and Serra (2003) find that foreign bank penetration is significantly higher between countries that have similar legal origins, banking regulations and institutional set ups, presumably as costs of operating and risks are lower in such countries. 
Here, we argue that a bank's competitive advantage due to familiarity with working in a certain investment climate can be another important determinant of foreign bank entry. In the general FDI literature, the internalization theory has been developed to explain why and how firms expand abroad. The theory asserts that firms expand abroad to exploit the knowledge advantage created within the firm. The concept of internal knowledge used is a very broad one and includes technical know-how, marketing knowhow and managerial know-how (see Casson, 1987). To benefit most of this internal knowledge-advantage, firms are best off to expand to an environment that is most equal to the environment they are already familiar with (as the skills they are internalizing are better suited to do business in a similar climate) (Buckley and Casson, 1991).

For banks, the concept of internal knowledge has mostly been used in respect to information asymmetries and principal agent issues. It has been established, theoretical and empirically, that banks can derive informational advantages from long-term bankclient relationships (see Petersen and Rajan, 1994 and Rajan, 1998). This can allow banks to offer their customers informational-intensive financial services at better terms than other banks and anonymous financial markets may. More generally, and in terms of explaining why and how banks expand abroad, the internalization theory would suggest that banks enter countries with similar level of information intensity and, more generally, similar institutional environments. So, a bank used to work in an opaque institutional environment, might be better able to exploit its knowledge advantage in a country which is also opaque. Vice-versa for a bank that is used to working in a very transparent country without corruption, other things being equal, it would be suboptimal to expand to a country with much opaqueness and a high level of corruption. ${ }^{1}$ This would suggest that institutional differences limit the expansion of banks' activities across borders. This hypothesis is supported by the empirical work of Galindo et al. (2003), who find that foreign bank penetration is greater between source and host countries that have more legal and institutional similarities.

\footnotetext{
${ }^{1}$ This argument is supported by evidence that large and small banks operate differently. There is evidence, for example, for the U.S. that small banks are better than large banks in lending to SMEs, which are informationally more opaque, as large banks rely more on hard information to do their lending. Since consolidation of the US banking system has led to a greater distance, it has thereby led to less lending to the more soft-information intensive SMEs (Berger, Miller, Petersen, Rajan and Stein, 2005).
} 
The above argument implicitly assumes that the location decision of an individual bank is made independent of the location decision made by other, competing, multinational banks that are also expanding their business abroad and want to determine their choice of location. When a firm decides to expand its business abroad, however, the choice of location is not just dependent on the firm's own internal advantage, but also on the competitive advantage that the investing firm has both over domestic firms but also over other foreign firms. To the extent that sources of internal competitive advantages are derived from the ability to work within a certain institutional environment, this implies that it may not just be the difference between the institutional quality in host and source country that matters for location decisions, but rather the difference between host and source country taking into account the institutional quality of the competitors. The impact of this type of competitiveness on location attractiveness of any type of foreign investment has, to our knowledge, not been studied before. The location decision of foreign banks, an institutionally-intensive sector, provides a good test how institutional differences can lead to competitive advantages and how they maybe dealt with.

In our study, we test therefore whether competitive advantage arising from working in a certain investment climate is an important determinant of foreign bank entry. In order to do so, we first construct a database covering most banks in all developing countries, including their ownership and the source country of all foreign owners. This database allows us to test whether better knowledge about a certain business environment compared to a bank's competitors is a determining factor in its decision to enter a certain market. We next construct a measure of a bank's competitive advantage as it relates to institutional environments. We find that controlling for a large number of variables already established to determine bank entry, the level of institutional development in the host country itself does not seem to impact cross-border entry activity. The same holds for differences in institutional development between host and source countries. However, we find strong evidence that similarities in institutions between host and source country compared to competitors affect a bank's entry decision. In other words, it is not the absolute level of the institutional environment faced by a firm that prevents it from entering a certain market, but rather its ability to work within a certain institutional environment better than its competitors. This shows that competitive 
advantage related to institutional environment is indeed an important driving factor in entry decisions made by foreign banks.

The rest of the paper is structured as follows. In Section 2 we describe the database used for foreign bank entry and show some statistics that indicate the potential importance of competitive advantage. In Section 3 we describe the methodology used and Section 4 includes the results. The last section concludes.

\section{Data and importance of competitive advantage}

\section{Bank Entry Data}

To test our hypothesis whether the location decision of foreign banks is driven by competitive advantage, we need to construct a database that contains information on both the host country of FDI as well as the source country of ownership. Our primary source of information is Bankscope. This is an international data set of balance-sheet items and ownership information of individual banks. All the main information on assets and liabilities and revenues is reported according to a common standard which is comparable across countries. The coverage is comprehensive, with banks included roughly accounting for 90 percent of the assets of banks in each country.

Foreign presence in the banking sector is highly concentrated among developed countries, which share almost similar levels of institutional quality. This presence also often dates back from entry long ago. To test our competitive advantage hypothesis we need variation in institutional quality between the possible host countries a foreign bank can choose from. Furthermore, we want to study entry decisions - rather than presence, which have been more intense in the last decade for developing countries than for developed countries. For these two reasons, we limit our sample to foreign bank entry in developing countries. The source countries in our sample include of course both developed and developing countries.

Countries with less than five active banks in Bankscope are excluded from our sample. A few developing countries are offshore centers (Barbados, Lebanon, Mauritius, and Panama). As decisions to enter those markets are often driven by tax incentives we exclude these countries from our sample. Information on ownership for banks located in 
Guatemala is very limited, so we also excluded this country. These restrictions leave us with a total of 98 developing countries. This sample includes both low and middleincome developing countries, providing a wide variety in income levels and, as such, institutional quality. Furthermore, it includes host countries from all regions, making it possible to control for regional differences.

Our sample includes all active commercial banks, saving banks, cooperative banks, bank holding companies and middle and long term credit banks that are reporting to Bankscope at end 2005. We assume a bank is foreign owned if 50 percent or more of the shares of a bank is owned by foreigners. The source country of the foreign owner is determined by looking at the direct shareholder structure. The percentages of shares are summed by country of residence of the shareholder. The country with the highest percentage of shares is appointed as the source country. When ownership information is not available in Bankscope, information is gathered from banks' websites or other internet sources. Ownership data are based on information available as of end 2005. We have ownership information for 2,297 banks, of which 35 percent are foreign owned.

\section{Preliminary evidence}

If our competitive advantage hypothesis is correct we should find that, taking the behavior of competitors into account, banks that work in countries with high levels of institutional quality tend to go to developing countries with relative high or average levels of institutional quality. On the other hand, banks headquartered in countries with weak institutions will tend to go to developing countries on the lower end of the institutional quality scale. So, when looking at the relationship between institutional quality in host and source country, a positive correlation should exist. The scatter plots presented in Figure 1 show that this is indeed the case.

Figure 1 displays six scatter plots. In each one, a measure of institutional quality in the host country is plot against the same indicator of the source country when at least one bank from the source country entered the host country. As measures of institutional quality we use the governance indicators constructed by Kaufmann, Kraay and Mastruzzi (2005). These indicators measure six dimensions of governance: (1) voice and accountability, (2) political instability and violence, (3) government effectiveness, (4) 
regulatory quality, (5) rule of law and (6) control of corruption. For each dimension they created an index that ranges from -2.5 to 2.5 with higher values indicating a lower burden. These measures have often been used in the literature to determine the impact of institutional quality on the location of FDI in general and FDI in banking in particular (see, for example, Galindo et al., 2003 and Stein and Daude, 2004).

All relationships displayed in Figure 1 are positive and highly significant. ${ }^{2}$ If absolute differences were driving entry decisions, we would expect a scatter around the 45 degree line, but this is not what we find in the plots. In other words, the positive correlation between institutional quality in host and source country does not seem to be driven by minimizing absolute differences and provides some preliminary evidence that competitive advantage might play a role in the location decisions of banks.

The study of Van Horen (2006) also provides some indication of the importance of competitive advantage in location decisions. This study finds that foreign bank ownership by banks from developing countries is more significant in low-income than in middle-income countries, while banks headquartered in a rich country are more strongly represented in middle income developing countries. The fact that foreign banks in developing countries are mostly from middle income developing countries suggests that competitive advantage over foreign competitors may be important in location decisions. By being more familiar — as compared to banks from rich, developed countries — with the more challenging investment climate in developing countries, banks from middle-income countries may have a competitive advantage over foreign competitors in low-income countries. Vice-versa, for banks from high-income countries, it may be easier to operate in middle-income countries. If similarity in institutional quality mattered most for banks' entry, instead of competitive advantage, banks from middle-income countries would largely invest in other middle-income countries and not in low-income countries.

\footnotetext{
2 The individual indicators are based on their value in 2000. However, correlations are very similar when taking the values for different years.
} 


\section{Hypothesis formulation and empirical methodology}

In this section we test formally whether competitive advantage over foreign competitors impacts location decisions of multinational banks. This is summarized in our “competitive advantage” hypothesis:

Hypothesis: Banks that are used to working in a country with relatively weak institutions compared to their competitors will expand to countries with relatively weak institutions, while banks that are more familiar with working in a country where institutions are well-functioning compared to their competitors will tend to enter countries with relatively good institutions.

The scatter plots presented in the previous section provide obviously only a very rough indication of the impact of competitive advantage on location decisions. First, if similarity in host and source countries' institutional environment would explain the location decision of firms, the correlations shown in the previous section should also be positive. In other words, to determine whether it is indeed competitive advantage due to familiarity with the environment that explains location decisions, one needs to construct a variable that takes the quality of institutions of the host and source country, but also that of the competitors into account. Second, there are a number of variables that may affect the location decision, which need to be controlled for. In this section, we will therefore develop a formal measure of competitive advantage and estimate a gravity model of bilateral FDI in banking, to determine whether indeed competitive advantage explains the location decision of foreign banks, in addition to the normal control variables.

\section{Measure of foreign bank presence}

In order to determine the impact of competitive advantage on the spread of foreign banks across countries, we need to use bilateral data. As described above, our data include 98 host countries and for all foreign banks in those countries, we determine the country of residence of the owner, or the so-called source country. For each host country, we construct country-pairs with all possible source countries in the sample. We restrict the 
source countries to all developed and developing countries that have a presence in the banking sector of at least one developing country. This to avoid a bias in the estimation due to the fact that some potential source countries might have capital account restrictions or other economic or institutional factors that make it impossible for their banks to expand to other countries and for which we cannot easily control. In addition source countries that are offshore centers are excluded. This leaves us with a total of 6,382 country-pair observations.

Following Galindo et al. (2003), we use as the dependent variable a measure of overall foreign bank penetration. For each host country, we determine per source country the sum of assets of foreign owned banks and divide that by the total amount of banks' assets in the host country. Bank assets come from Bankscope and are based on the consolidated balance sheets. ${ }^{3}$

\section{Measure of competitive advantage}

Our hypothesis implies that firms that are more familiar with working in a country where institutions are weak compared to their competitors will tend to invest in host countries with weak institutions. At the same time, firms whose home country has strong institutions are more likely to go to countries with good institutions as they have a hard time competing in host countries with weak institutions. To model this, we interact the institutional quality in the host country with the difference between the institutional quality in the source country and that of all the bank's competitors. In other words, competitive advantage that a source country $j$ has in host country $i$ is defined as:

$$
\operatorname{CompAdv}_{i j}=\text { Insthost }_{i}\left(\text { Instsource }_{j}-\text { Instcomp }\right)
$$

The institutional quality of the competitors, Instcomp, is measured by taking the weighted average of the institutional quality in each of the possible source countries. The weight of each country is determined by its size, proxied by its dollar GDP. The measure of competitive advantage can be positive or negative, depending on whether in terms of

\footnotetext{
${ }^{3}$ In order to minimize the effects of particular events, data on banks' assets are averages of annual values from 2000-2004.
} 
institutional quality the source country is above of below the average of competitor countries.

Our specific measure of institutional quality in the host country is the simple average of the six governance indicators identified by Kaufmann et al. (2005) discussed in the previous section. Although, taking the simple average can hide certain indicatorspecific effects on foreign bank entry, we believe this bias is limited as correlation

between the six indicators is very high, ranging from 0.60 to 0.96 . However, in a robustness test, we test whether our results are different when using the individual indicators. The original indicators of Kaufmann et al. (2005) vary between -2.5 and 2.5, which makes it harder to interpret the results. To avoid this, before constructing the competitive advantage variable, we linearly transform the original indicators so their value is never below zero. Data for 2000 are used to minimize bias in the estimation due to endogeneity, e.g., foreign entry raising the institutional quality of the host country.

A positive sign of the competitive advantage variable would suggest that if the institutions of the source country are better than that of its competitors, good institutions in the host country have a positive impact on foreign bank entry. If, on the other hand, the institutions in the source country are weak relative to that of the competitors, banks from this country will be more inclined to locate in countries with weak institutions. In other words, for our competitive advantage hypothesis to hold the variable should be significant and have a positive sign.

\section{Empirical framework}

In order to explain FDI in the banking sector of developing countries, we use a gravity model. The gravity model has been used extensively to explain trade patterns. Recently the gravity model has been applied more frequently in studies on explaining FDI (see, among others, Galindo et al, 2003, Di Giovanni, 2005, and Van Horen, 2006). The model in its most simple format explains bilateral flows (i.e., trade or investment) between two countries on the basis of the product of the GDPs of both countries, and the distance between them. The model is typically extended by including dummies that indicate whether the two countries share a common border, common language, past colonial links, possibly time-zone and other geographical information etc. 
To test our competitive advantage hypothesis, we estimate how the size of foreign-controlled assets from source country $j$ in host country $i$ is related to institutional quality in the host country and to our measure of competitive advantage. If our hypothesis is correct, the quality of institutions in the host country should not matter. After all, when facing a decision to enter another country, banks from certain countries will be attracted to countries with well-functioning institutions while others by countries with weak institutions depending on the quality of institutions in their home country. At the same time the relative level of institutional quality should be significant and have a positive sign.

We first include standard gravity model variables like common border, common language, past colonial links and distance between the countries, and GDP of host and source country. These variables have proven to have explanatory power as drivers of foreign bank entry (see Galindo et al., 2003). Furthermore, we include trade between the two countries and a dummy that captures whether the legal systems of the countries are from the same origin. ${ }^{4}$ In addition, we include a measure of the financial depth of the host country and a dummy that captures whether foreign bank entry is restricted in the host country. To capture differences in the magnitude of foreign bank entry in different regions of the developing world, we also include regional dummies. We did not use country dummies to capture source country specific effects. Since FDI takes only place in a small portion of our country pairs, adding source country dummies could potentially create a bias in our estimations. To capture some of the source country characteristics that could explain the decision to enter a foreign market, we include, besides the size of the source country economy also its GDP per capita. To limit the possibility that our results are affected by endogeneity, we use for all explanatory variables that are time-varying only their levels in 2000. For a complete description of all variables in the model, see the appendix.

Our benchmark model is as follows:

\footnotetext{
${ }^{4}$ Another useful indicator would be bilateral FDI flows, but data are not available, and FDI flows are highly correlated with trade flows, which is included in the model.
} 
ForCont $_{i j}=\alpha_{1}$ Insthost $_{i}+\alpha_{2}$ CompAdv $_{i j}+\alpha_{3}$ Collinks $_{i j}+\alpha_{4}$ Border $_{i j}+\alpha_{5}$ Comlang $_{i j}$

$+\alpha_{6}$ Distance $_{i j}+\alpha_{7}$ Trade $_{i j}+\alpha_{8}$ LegalDif $_{i j}+\alpha_{9}$ GDPhost $_{i}+\alpha_{10}$ FinDepthhost $_{i}$

$+\alpha_{11}$ Entryres $+\alpha_{12}$ GDPsource $_{j}+\alpha_{13}$ GDPcapsource $_{j}+\alpha_{14}$ DRegion $+\varepsilon_{i j}$

where $i$ refers to the host country and $j$ to the source country. We estimate our gravity model using Tobit to account for the many zeros in the dependent variable. In addition, the standard errors are corrected for heteroskedasticity,

\section{Results}

Does competitive advantage matter?

Using regression model (1) we test whether familiarity with the type of business climate relative to its competitors, matters in a bank's decision which country to enter. Before turning to the regression results, we first estimate the model excluding the competitive advantage variable but including the measure of institutional quality in the host country and the absolute difference between institutional quality in the host and source country respectively. The latter variable is constructed by taking the simple average of the absolute difference of each of the six governance indicators.

Table 1 presents the results. To aid the economic interpretation we show, instead of parameter estimates, the marginal effects of the unconditional expected value of the dependent variable, $\mathrm{E}(\mathrm{y})$, where $\mathrm{y}=\max \left(a, \min \left(\mathrm{y}^{*}, b\right)\right)$ where $a$ is the lower limit for left censoring (0) and $b$ is the upper limit for right censoring (100). The marginal effects are calculated at the mean of the independent variable, except when the independent variable is a dummy in which case the marginal effect is calculated as the change in the dummy variable from 0 to 1 . The marginal effects capture the combined effect of the impact of the explanatory variable on the probability of entering the host country as well as on the amount of FDI. The mean of the dependent variable is equal to 0.57 percent.

The first two columns in the table show that both institutional quality of the host country as well as the difference in institutional quality have no statistically significant impact on cross-border banking activity. In fact, the variable capturing differences in institutional quality has a, counterintuitive, positive sign, although not statistically 
significant. These results would suggest that the average bank expanding abroad does not consider the institutional quality of the host country in which it wants to invest. However, these results do not consider the possibility that banks that want to expand abroad might have different reactions to the level of institutions in the host country.

As is shown in the third column of Table 1, we indeed find that institutional quality matters in a bank's entry decision, but differently for banks located in different countries. As in the first regression, we find that institutional quality of the host country is insignificant. However, we find that our competitive advantage variable is positive and highly significant, suggesting support for the competitive advantage hypothesis. The result suggests that for banks which, compared to their competitors, come from countries with good institutions, a high institutional quality in the host country will make it more likely that they engage in cross-border banking. On the other hand, for banks that are familiar in working in a country where institutions are weak, a better institutional quality will be a deterrent for cross-border banking.

The impact of competitive advantage on foreign bank presence is economically very relevant and the results show the opposite effects of institutional quality between high and low institutional quality source countries. The parameter estimate, which reflects the marginal effect, can be interpreted as follows: for the source country that has the highest level of institutional quality (Finland), its banks' share in foreign markets would increase by 0.1 percent when moving from a host country with the lowest institutional quality (Democratic Republic of Congo) to a host country with the highest institutional quality (Chile). This is a substantial increase considering that the mean of foreign presence in all host countries is 0.57 percent. In other words, banks from the best institutional quality source countries are willing to increase their presence by some 20 percent if a country's institutional quality increases from the lowest to the highest. At the same time, the source country with the lowest level of institutional quality (Libya) would find its share in total assets of the host country drop by 0.31 percent when moving from the country with the lowest institutional quality to the one with the highest institutional quality, or a drop of more than 50 percent. For a bank from a country like Libya, operating in a high quality (source) country is not consistent with its competitive 
advantage, while for a bank from a country like Finland, operating in a high quality (source) country is consistent with its competitive advantage.

The coefficients of the control variables in all equations are mostly as expected. Colonial links between source and host country have a strong positive impact on foreign control. A common language, which reduces the cost of foreign banking, is a significant determinant for foreign bank entry, while distance is negatively related to foreign banking. After controlling for distance, a common border is not a significant determinant anymore. The fact that trade is positive and significant, indicates that banks tend to follow their customers. Surprisingly, differences in legal systems, which arguably increase the cost for a foreign bank to operate across borders, has no impact on foreign bank entry. The economic size of the country has a positive impact on foreign bank entry, possibly reflecting the importance of scale for entry. However, the depth of the financial sector does not have an independent impact, which may be due to two offsetting effects. A well developed financial system suggests a better operating environment, also for foreign banks, making entry more likely. At the same time, a well developed system may make for fewer opportunities for foreign banks to expand into and make profits. In addition, depth of the financial sector might attract banks from rich countries while it deters banks from developing countries (see Van Horen, 2006). As expected, restrictions on foreign entry negatively affect the presence of foreign banks. Finally, the size and the income level of the source country have a positive impact on foreign banking presence.

Summarizing, the results suggest that FDI decisions are not so much influenced by the absolute differences in institutional environment between source and host countries faced by a bank, but rather by a given bank's ability to cope with these differences better than other, competitor banks. In other words, banks that are willing to expand their business abroad seek out those markets in which their past experience in working in a certain business climate gives them a competitive advantage.

\section{Sensitivity analysis}

In our benchmark model we took as a measure of institutional quality the simple average of the six different institutional indicators. This could have biased our results since the average may hide the fact that competitive advantage arises with respect to a certain kind 
of institutional indicator but does not with respect to others. Furthermore, it provides limited insight into the source of competitive advantage. Being familiar with working in a country where corruption is rampant does not necessarily make you better equipped to work in a country where there is, for example, political instability and violence, than a competitor who is not used to working in that business climate. The average measure of institutional quality, however, does not allow one to distinguish between the two types of institutional weaknesses.

Table 2 shows that for all individual indicators the result continues to hold that competitive advantage is an important determinant of the location decision of foreign banks. Interpreting the marginal effect of the competitive advantage variable of the respective indicators suggests the following. The source country with the lowest rating regarding voice and accountability sees a drop of 0.22 percent in the total assets it controls in the host country with the highest rating regarding voice and accountability as compared to the host country with the lowest rating. In the case of political instability and violence this drop is 0.19 percent, for government effectiveness and rule of law it amounts to 0.35 percent, while foreign control drops with respectively 0.33 and 0.28 percent in the case of regulatory quality and control of corruption. These percentages are very much in line with the results we found when using the average institutional quality variable.

\section{Conclusion}

The literature on foreign banking has identified several factors to influence the location decision of multinational banks. In this paper we add to this literature by examining whether the competitive advantage of one foreign bank over its competitors in a specific host country due to its better knowledge of the institutional environment is a determining factor in a bank's decision to enter a certain market.

Our results suggest that it is not the level of institutional quality per se or the similarities in institutional quality between host and source country that have a determining impact on the location decision, but rather that similarities in institutions between host and source country as compared to the bank's competitors determine entry 
decisions. This implies that for those banks that compared to their competitors, are used to work in countries with good institutions, high institutional quality will have a positive impact on cross-border banking, while for banks that are more familiar with working in a country where institutions are weak, a worse institutional quality can be a competitive advantage reason to enter foreign markets.

This result is important from a policy perspective as it shows that high institutional quality is not necessarily a prerequisite to be able to attract foreign direct investment in banking. As the development of the financial sector is an engine for growth in developing countries and foreign banks tend to have a beneficial impact on the domestic financial system, this is potentially good news for low-income developing countries. However, some caution is warranted for. We find that banks that can use their competitive advantage entering in institutionally less developed countries are more likely to come from other institutionally less developed countries. This could potentially create costs. One cost is that these foreign banks become a source of instability in the host countries, for example, because they lack supervision in their source country. In addition, these foreign banks may take advantage of the weak institutional environment in the host countries and, for example, exploit the safety net provided to banks by taking on excessive risks. As such, foreign banks can be immiserizing.

As such our results suggest a further research agenda. One area of future research is to investigate in more detail the source of competitive advantage. Is it that foreign banks from a weak institutional environment are better able to deal with a weak contracting environment, and can therefore easier make loans? Or is it that banks from a weak institutional environment are more willing to take advantage of a weak supervisory structure in host countries? One way to differentiate these hypotheses is to use additional and more specific measures of institutional differences to trace the source of competitive advantage. Another, complementary way is to investigate the impact of foreign banks entry from different countries on the financial system, especially of low-income countries. Neither area has yet been studied. 


\section{References:}

Barth, J., G. Caprio, and R. Levine, 2006, Rethinking Bank Regulation; Till Angels Govern, New York: Cambridge University Press.

Berger, A. N., N. H. Miller, M. A. Petersen, R. Rajan, and J. Stein, 2005, “Does Function Follow Organizational Form? Evidence from the Lending Practices of Large and Small Banks,” Journal of Financial Economics, vol. 76, pp. 237-269.

Brealey, R., and E.C. Kaplanis, 1996, “The Determination of Foreign Banking Location,” Journal of International Money and Finance, vol. 15, pp. 577-597.

Buckley, P. J. and M. Casson, 1991, The Future of the Multinational Enterprise, $2^{\text {nd }}$ Edition, London: MacMillan.

Casson, M., 1987, The Firm and the Market, London: Allen and Unwin.

Di Giovanni, J., 2005, "What Drives Capital Flows? The Case of Cross-border M\&A Activity and Financial Deepening,” Journal of International Economics, vol. 65, pp. 127-149.

Easterly, W. and M. Sewadeh, 2001, “Global Development Network Growth Database,” Washington, DC, TheWorld Bank.

Focarelli, D. and A. Pozzolo, 2000, "The Determinants of Cross-Border Bank Shareholdings: An Analysis with Bank-Level Data from OECD Countries," Federal Reserve Bank of Chicago, Proceedings (May), pp. 199-232.

Galindo, A., A. Micco, and C. Serra, 2003, "Better the Devil That You Know: Evidence on Entry Costs Faced by Foreign Banks,” Inter American Development Bank Working Paper No. 477.

Grosse, R. and L.G. Goldberg, 1991, "Foreign Bank Activity in the United States: An Analysis by Country of Origin,” Journal of Banking and Finance, vol. 15, pp. 1092-1112.

Kaufmann, D., A. Kraay, and M. Mastruzzi, 2005, “Governance Matters IV: Governance Indicators for 1996-2004,” Washington, DC, The World Bank.

Petersen, M.A. and R. Rajan, 1994, "The Benefits of Lending Relationships: Evidence from Small Business Data,” Journal of Finance, vol. 49, pp. 3-38.

Rajan, R., 1998, "The Past and Future of Commercial Banking Viewed through an Incomplete Contract Lens,” Journal of Money, Credit and Banking, vol. 30, pp. 524-551.

Stein, E. and C. Daude, 2004, “Quality of Institutions and Foreign Direct Investment,” Mimeo: University of Maryland and Inter-American Development Bank.

Van Horen, 2006, "Foreign Bank Entry in Developing Countries: Origin Matters," Mimeo, The World Bank.

Williams, B., 1998, "Factors Affecting the Performance of Foreign-Owned Banks in Australia: A Cross-Sectional Study,” Journal of Banking and Finance, vol. 22, pp. 197-219.

Yamori, N., 1998, “A Note on the Location Choice of Multinational Banks: the Case of Japanese Financial Institutions,” Journal of Banking and Finance, vol. 22, pp. 109-120. 


\section{Table 1 - Competitive Advantage in Foreign Banking}

The dependent variable is the ratio of the sum of assets of foreign banks in host country $i$ that are owned by banks from source country $j$, divided by the total amount of bank assets in host country $i$. Insthost is the simple average of six indicators of quality of institutions in the host country in 2000 as measured by Kaufmann, Kraay and Mastruzzi (2005). DiffInst is the absolute difference between quality of institutions of source and host countries. CompAdv is defined as Insthost*(Instsource-Instcomp), see main text for explanation. Collinks is dummy which is 1 if host and source country have had colonial links either between colonizer and colony or between those countries having been colonized by the same colonizer. Border is dummy which is 1 if the countries share a border. Comlang is dummy which is 1 if the countries share the same language. Distance refers to the log of the distance between the host and source countries. Trade is the log of export plus import in 2000 between the two countries. Legaldif is a dummy which is 1 if the origin of the legal system of host and source country differ. GDPhost is the log of the host country's GDP in 2000. FinDepthhost is the log of M2 as percentage of GDP in the host country in 2000. Entryres is dummy which is 1 if foreign bank entry is restricted. GDPsource and GDPcapsource are the log of respectively GDP and GDP per capita in the source country in 2000. Dregion are dummies for each region, South-Asia is the ommited region. All regressions include a constant. Coefficients are marginal effects. The robust p-values appear in brackets and ${ }^{* * *}, * *$ and $*$ correspond to one, five and ten percent level of significance respectively.

\begin{tabular}{|c|c|c|c|}
\hline & (1) & (2) & (3) \\
\hline Insthost & $\begin{array}{r}-0.012 \\
{[0.429]}\end{array}$ & & $\begin{array}{r}-0.004 \\
{[0.788]}\end{array}$ \\
\hline DiffInst & & $\begin{array}{r}0.019 \\
{[0.133]}\end{array}$ & \\
\hline CompAdv & & & $\begin{array}{c}0.042 * * * \\
{[0.000]}\end{array}$ \\
\hline Collinks & $\begin{array}{c}0.652 * * * \\
{[0.000]}\end{array}$ & $\begin{array}{l}0.640 * * * \\
{[0.000]}\end{array}$ & $\begin{array}{c}0.534 * * * \\
{[0.000]}\end{array}$ \\
\hline Border & $\begin{array}{r}0.023 \\
{[0.523]}\end{array}$ & $\begin{array}{r}0.025 \\
{[0.492]}\end{array}$ & $\begin{array}{r}0.048 \\
{[0.197]}\end{array}$ \\
\hline Comlang & $\begin{array}{l}0.175 * * * \\
{[0.000]}\end{array}$ & $\begin{array}{l}0.171 * * * \\
{[0.000]}\end{array}$ & $\begin{array}{l}0.167 * * * \\
{[0.000]}\end{array}$ \\
\hline Distance & $\begin{array}{l}-0.136 * * * \\
{[0.000]}\end{array}$ & $\begin{array}{l}-0.136 * * * \\
{[0.000]}\end{array}$ & $\begin{array}{l}-0.121 * * * \\
{[0.000]}\end{array}$ \\
\hline Trade & $\begin{array}{l}0.010 * * * \\
{[0.000]}\end{array}$ & $\begin{array}{c}0.010 * * * \\
{[0.000]}\end{array}$ & $\begin{array}{l}0.008 * * * \\
{[0.001]}\end{array}$ \\
\hline LegalDif & $\begin{array}{r}-0.002 \\
0.9011\end{array}$ & $\begin{array}{r}-0.004 \\
-0.811]\end{array}$ & $\begin{array}{r}-0.018 \\
0.273]\end{array}$ \\
\hline GDPhost & $\begin{array}{l}0.027 * * * * \\
{[0.000]}\end{array}$ & $\begin{array}{l}0.027 * * * \\
{[0.000]}\end{array}$ & $\begin{array}{c}0.025 * * * \\
{[0.000]}\end{array}$ \\
\hline FinDepthhost & $\begin{array}{r}-0.021 \\
{[0.183]}\end{array}$ & $\begin{array}{r}-0.020 \\
{[0.183]}\end{array}$ & $\begin{array}{r}-0.019 \\
{[0.181]}\end{array}$ \\
\hline Entryres & $-0.040 * *$ & $\begin{array}{l}-0.040 * * * \\
{[0.008]}\end{array}$ & $-0.037 * * *$ \\
\hline GDPsource & $\begin{array}{l}0.054 * * * \\
{[0.000]}\end{array}$ & $\begin{array}{l}0.054 * * * \\
{[0.000]}\end{array}$ & $\begin{array}{c}0.052 * * * \\
{[0.000]}\end{array}$ \\
\hline GDPcapsource & $0.052 * * *$ & $0.042 * * *$ & -0.018 \\
\hline Dregion=East Asia and Pacific & $\begin{array}{l}0.410 * * * \\
{[0.005]}\end{array}$ & $\begin{array}{l}0.415 * * * \\
{[0.004]}\end{array}$ & $\begin{array}{l}0.461 \\
{[0.002]}\end{array}$ \\
\hline Dregion=Europe and Central Asia & $\begin{array}{c}0.209 * * \\
{[0.024]}\end{array}$ & $\begin{array}{c}0.214 * * \\
{[0.020]}\end{array}$ & $\begin{array}{c}0.247 \text { ** } \\
{[0.010]}\end{array}$ \\
\hline Dregion $=$ Latin Americ and Caribbean & $\begin{array}{c}0.441 * * * * \\
{[0.000]}\end{array}$ & $\begin{array}{l}0.445 * * * \\
{[0.000]}\end{array}$ & $\begin{array}{c}0.431 * * * \\
{[0.000]}\end{array}$ \\
\hline Dregion $=$ Middle East and Northern Africa & $\begin{array}{r}0.000] \\
-0.016 \\
{[0.773]}\end{array}$ & $\begin{array}{r}-0.015 \\
{[0.787]}\end{array}$ & $\begin{array}{r}0.001 \\
{[0.987]}\end{array}$ \\
\hline Dregion $=$ Sub-Saharan Africa & $\begin{array}{c}0.519 * * * \\
{[0.000]}\end{array}$ & $\begin{array}{l}0.519 * * * \\
{[0.000]}\end{array}$ & $\begin{array}{c}0.501 * * * \\
{[0.000]}\end{array}$ \\
\hline No. Obs. & 5,532 & 5,532 & 5,532 \\
\hline
\end{tabular}


Table 2 - Robustness test; individual indicators

The dependent variable is the ratio of the sum of assets of foreign banks in host country $i$ that are owned by banks from source country $j$, divided by the total amount of bank assets in host country $i$. InstIndhost is one of six indicators of quality of institutions in the host country in 2000 as measured by Kaufmann, Kraay and Mastruzzi (2005). In the regression (1) this is voice and accountability, in regression (2) politial instability and violence, in regression (3) government effectiveness, in (4) regulatory quality in (5) rule of law and in the last regression InstIndhost indicates control of corruption. CompAdvInd is defined as InstIndhost*(InstIndsource-InstIndcomp), see main text for explanation. Collinks is dummy which is 1 if host and source country have had colonial links either between colonizer and colony or between those countries having been colonized by the same colonizer. Border is dummy which is 1 if the countries share a border. Comlang is dummy which is 1 if the countries share the same language. Distance refers to the log of the distance between the host and source countries. Trade is the log of export plus import in 2000 between the two countries. Legaldif is a dummy which is 1 if the origin of the legal system of host and source country differ. GDPhost is the log of the host country's GDP in 2000. FinDepthhost is the log of M2 as percentage of GDP in the host country in 2000. Entryres is dummy which is 1 if foreign bank entry is restricted. GDPsource and GDPcapsource are the log of respectively GDP and GDP per capita in the source country in 2000. Dregion are dummies for each region, South-Asia is the ommited region. All regressions include a constant. Coefficients are marginal effects. The robust p-values appear in brackets and ***, ** and * correspond to one, five and ten percent level of significance respectively.

\begin{tabular}{|c|c|c|c|c|c|c|}
\hline & (1) & (2) & (3) & (4) & (5) & (6) \\
\hline InstIndhost & -0.003 & -0.006 & 0.010 & -0.001 & -0.003 & -0.012 \\
\hline & {$[0.828]$} & [0.568] & {$[0.475]$} & {$[0.935]$} & {$[0.816]$} & {$[0.338]$} \\
\hline CompAdvInd & $\begin{array}{l}0.027 \text { *** } \\
{[0.001]}\end{array}$ & $\begin{array}{c}0.017 \text { ** } \\
{[0.019]}\end{array}$ & $\begin{array}{l}0.0411^{* * *} \\
{[0.000]}\end{array}$ & $\begin{array}{c}0.026 * * * \\
{[0.000]}\end{array}$ & $\begin{array}{l}0.045 * * * \\
{[0.000]}\end{array}$ & $\begin{array}{l}0.038 * * * \\
{[0.000]}\end{array}$ \\
\hline Collinks & $\begin{array}{l}0.650 \text { *** } \\
{[0.000]}\end{array}$ & $\begin{array}{l}0.672 * * * \\
{[0.000]}\end{array}$ & $\begin{array}{l}0.545 * * * \\
{[0.000]}\end{array}$ & $\begin{array}{l}0.664 \text { *** } \\
{[0.000]}\end{array}$ & $\begin{array}{l}0.498 \text { *** } \\
{[0.000]}\end{array}$ & $\begin{array}{l}0.532 * * * \\
{[0.000]}\end{array}$ \\
\hline Border & $\begin{array}{r}0.029 \\
{[0.428]}\end{array}$ & $\begin{array}{r}0.030 \\
{[0.431]}\end{array}$ & $\begin{array}{r}0.049 \\
{[0.207]}\end{array}$ & $\begin{array}{r}0.037 \\
{[0.336]}\end{array}$ & $\begin{array}{r}0.053 \\
{[0.144]}\end{array}$ & $\begin{array}{r}0.052 \\
{[0.167]}\end{array}$ \\
\hline Comlang & $\begin{array}{l}0.1711^{* * *} \\
{[0.000]}\end{array}$ & $\begin{array}{l}0.1911^{* * *} \\
{[0.000]}\end{array}$ & $\begin{array}{l}0.169 \text { *** } \\
{[0.000]}\end{array}$ & $\begin{array}{l}0.168 \text { *** } \\
{[0.000]}\end{array}$ & $\begin{array}{l}0.143 * * * \\
{[0.000]}\end{array}$ & $\begin{array}{l}0.162 * * * \\
{[0.000]}\end{array}$ \\
\hline Distance & $\begin{array}{l}-0.132 * * * \\
{[0.00]}\end{array}$ & $\begin{array}{l}-0.140 * * * \\
{[0.000]}\end{array}$ & $\begin{array}{l}-0.127 * * * \\
{[0.000]}\end{array}$ & $\begin{array}{l}-0.131 * * * \\
{[0.000]}\end{array}$ & $\begin{array}{l}-0.112 * * * \\
{[0.000]}\end{array}$ & $\begin{array}{l}-0.122 * * * \\
{[0.000]}\end{array}$ \\
\hline Trade & $\begin{array}{l}0.009 * * * \\
{[0.000]}\end{array}$ & $\begin{array}{l}0.010 * * * \\
{[0.001]}\end{array}$ & $\begin{array}{l}0.008 * * * \\
{[0.002]}\end{array}$ & $\begin{array}{l}0.010 \text { *** } \\
{[0.001]}\end{array}$ & $\begin{array}{l}0.008 \text { *** } \\
{[0.001]}\end{array}$ & $\begin{array}{l}0.008 * * * \\
{[0.001]}\end{array}$ \\
\hline LegalDif & $\begin{array}{r}-0.005 \\
{[0.777]}\end{array}$ & $\begin{array}{l}-0.005 \\
{[0.778]}\end{array}$ & $\begin{array}{r}-0.017 \\
{[0.309]}\end{array}$ & $\begin{array}{r}-0.011 \\
{[0.530]}\end{array}$ & $\begin{array}{c}-0.027 \text { * } \\
{[0.086]}\end{array}$ & $\begin{array}{r}-0.017 \\
{[0.302]}\end{array}$ \\
\hline GDPhost & $\begin{array}{l}0.027 * * * \\
{[0.000]}\end{array}$ & $\begin{array}{l}0.025 * * * \\
{[0.000]}\end{array}$ & $\begin{array}{l}0.025 * * * \\
{[0.000]}\end{array}$ & $\begin{array}{l}0.025 * * * \\
{[0.000]}\end{array}$ & $\begin{array}{l}0.022 * * * \\
{[0.000]}\end{array}$ & $\begin{array}{l}0.024 * * * \\
{[0.000]}\end{array}$ \\
\hline FinDepthhost & $\begin{array}{c}-0.025 * \\
{[0.092]}\end{array}$ & $\begin{array}{r}-0.017 \\
{[0.308]}\end{array}$ & $\begin{array}{r}-0.023 \\
{[0.130]}\end{array}$ & $\begin{array}{r}-0.023 \\
{[0.133]}\end{array}$ & $\begin{array}{l}-0.013 * * * \\
{[0.346]}\end{array}$ & $\begin{array}{r}-0.012 \\
{[0.407]}\end{array}$ \\
\hline Entryres & $\begin{array}{l}-0.037 \text { ** } \\
{[0.018]}\end{array}$ & $\begin{array}{l}-0.037 * * \\
{[0.018]}\end{array}$ & $\begin{array}{l}-0.035 * * \\
{[0.020]}\end{array}$ & $\begin{array}{l}-0.040 * * \\
{[0.019]}\end{array}$ & $\begin{array}{l}-0.034 \text { ** } \\
{[0.010]}\end{array}$ & $\begin{array}{l}-0.037 \text { *** } \\
{[0.007]}\end{array}$ \\
\hline GDPsource & $\begin{array}{l}0.056 * * * \\
{[0.000]}\end{array}$ & $\begin{array}{l}0.059 * * * \\
{[0.000]}\end{array}$ & $\begin{array}{l}0.052 * * * \\
{[0.000]}\end{array}$ & $\begin{array}{l}0.056 * * * \\
{[0.000]}\end{array}$ & $\begin{array}{l}0.045 * * * \\
{[0.000]}\end{array}$ & $\begin{array}{l}0.051 \text { *** } \\
{[0.000]}\end{array}$ \\
\hline GDPcapsource & $\begin{array}{r}0.016 \\
{[0.319]}\end{array}$ & $\begin{array}{r}0.020 \\
{[0.319]}\end{array}$ & $\begin{array}{r}-0.004 \\
{[0.806]}\end{array}$ & $\begin{array}{r}0.005 \\
{[0.761]}\end{array}$ & $\begin{array}{r}-0.015 \\
{[0.330]}\end{array}$ & $\begin{array}{r}0.005 \\
{[0.731]}\end{array}$ \\
\hline Dregion $=$ East Asia and Pacific & $\begin{array}{l}0.440 \text { *** } \\
{[0.000]}\end{array}$ & $\begin{array}{l}0.452 * * * \\
{[0.003]}\end{array}$ & $\begin{array}{l}0.455 \text { *** } \\
{[0.003]}\end{array}$ & $\begin{array}{l}0.450 \text { *** } \\
{[0.003]}\end{array}$ & $\begin{array}{l}0.431 \text { *** } \\
{[0.003]}\end{array}$ & $\begin{array}{l}0.432 * * * \\
{[0.003]}\end{array}$ \\
\hline Dregion=Europe and Central Asia & $\begin{array}{l}0.212 * * \\
{[0.025]}\end{array}$ & $\begin{array}{l}0.239 * * \\
{[0.015]}\end{array}$ & $\begin{array}{l}0.229 * * \\
{[0.015]}\end{array}$ & $\begin{array}{l}0.235 * * \\
{[0.015]}\end{array}$ & $\begin{array}{l}0.249 \text { *** } \\
{[0.008]}\end{array}$ & $\begin{array}{l}0.247 \text { ** } \\
{[0.010]}\end{array}$ \\
\hline Dregion $=$ Latin Americ and Caribbean & $\begin{array}{l}0.422 * * * \\
{[0.000]}\end{array}$ & $\begin{array}{l}0.500 * * * \\
{[0.000]}\end{array}$ & $\begin{array}{l}0.443 * * * \\
{[0.000]}\end{array}$ & $\begin{array}{l}0.429 * * * \\
{[0.001]}\end{array}$ & $\begin{array}{l}0.461 * * * \\
{[0.000]}\end{array}$ & $\begin{array}{l}0.463 \text { *** } \\
{[0.000]}\end{array}$ \\
\hline Dregion $=$ Middle East and Northern Africa & $\begin{array}{r}-0.007 \\
{[0.899]}\end{array}$ & $\begin{array}{r}-0.012 \\
{[0.843]}\end{array}$ & $\begin{array}{r}-0.007 \\
{[0.898]}\end{array}$ & $\begin{array}{r}-0.005 \\
{[0.933]}\end{array}$ & $\begin{array}{r}-0.001 \\
{[0.978]}\end{array}$ & $\begin{array}{r}-0.003 \\
{[0.952]}\end{array}$ \\
\hline Dregion $=$ Sub-Saharan Africa & $\begin{array}{l}0.502 \text { *** } \\
{[0.000]}\end{array}$ & $\begin{array}{l}0.547^{* * *} \\
{[0.000]}\end{array}$ & $\begin{array}{l}0.494 * * * \\
{[0.000]}\end{array}$ & $\begin{array}{l}0.517 \text { *** } \\
{[0.000]}\end{array}$ & $\begin{array}{l}0.486 \text { *** } \\
{[0.000]}\end{array}$ & $\begin{array}{l}0.505 * * * \\
{[0.000]}\end{array}$ \\
\hline No. Obs. & 5,532 & 5,532 & 5,532 & 5,532 & 5,532 & 5,532 \\
\hline
\end{tabular}


Figure 1 - Simple Correlations of Institutional Quality

The figure shows the correlations between institutional quality in the host country of the foreign bank and the institutional quality in the country in which the foreign owner is headquartered (the source country) for each of the six governance indicators constructed by Kaufmann, Kraay and Mastruzzi (2005)
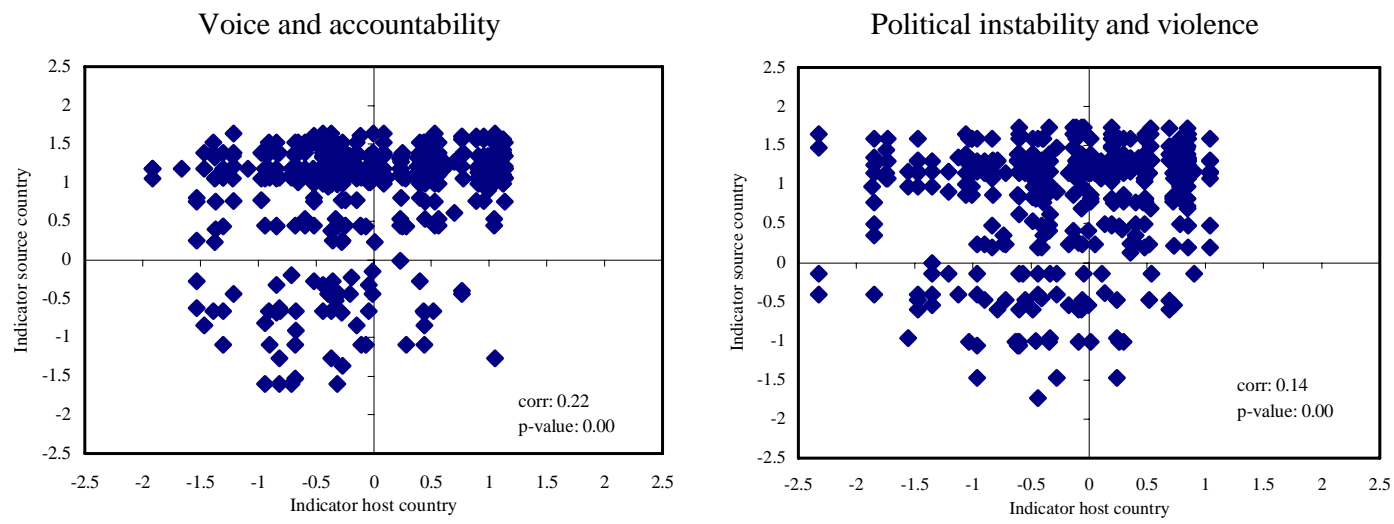

Government effectiveness

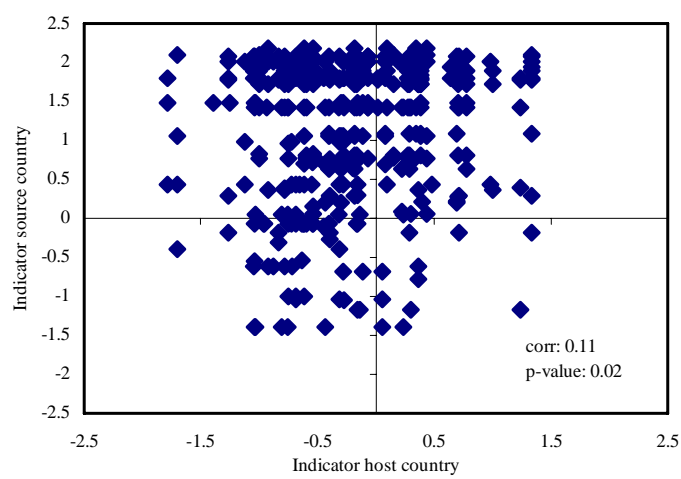

Regulatory quality

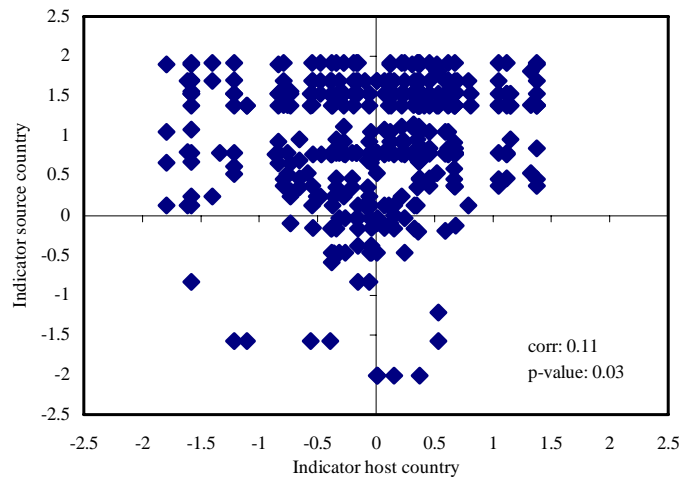

Rule of law

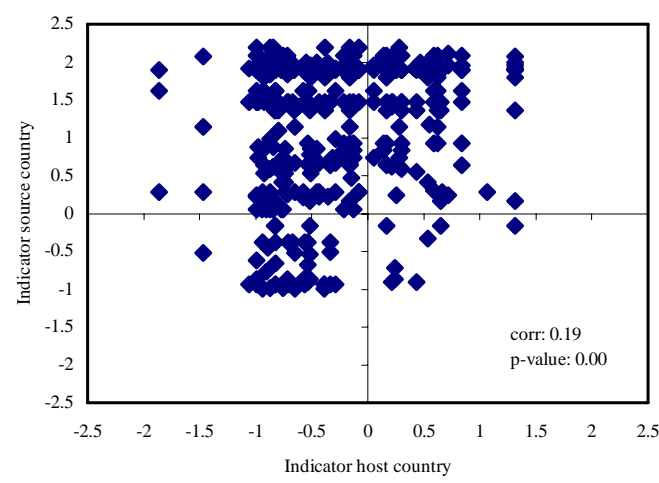

Control of corruption

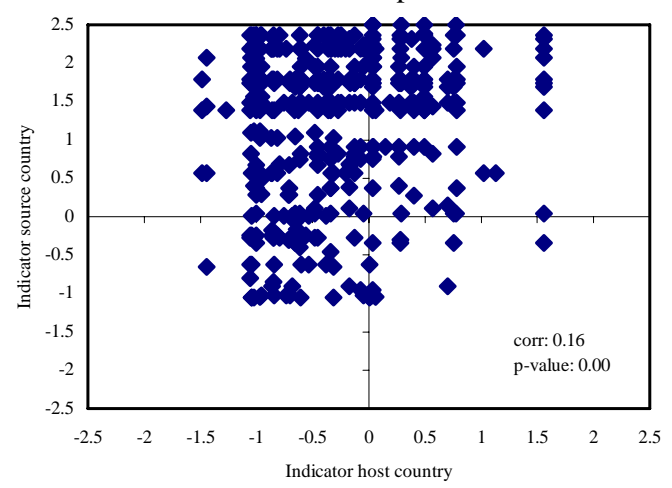




\title{
Appendix - Variable Definitions and Sources
}

\author{
Variable \\ Definition \\ Source \\ Ratio of the sum of assets of foreign banks in host country $i$ that are \\ owned by banks from source country $j$, divided by the total amount \\ of bank assets in host country $i$. \\ Insthost \\ The simple average of six indicators of quality of institutions in the \\ host country (voice and accountability, politial instability and \\ violence, government effectiveness, regulatory quality, rule of law \\ and control of corruption) measured in 2000. \\ DiffInst \\ The absolute difference between quality of institutions of source and \\ host countries measured in 2000, based on the simple average of the \\ absolute difference of each of the six indicators of quality of \\ institutions. \\ CompAdv \\ Institutional quality of the host country interacted with the difference \\ between the institutional quality of the source country and that of the \\ competitors. Institutional quality of competitors is measured by \\ taking the weighted average (based on GDP in current dollars) of the \\ institutional quality of each of the possible source countries. All \\ variables are measured in 2000. \\ Collinks \\ Dummy which is 1 if host and source country have had colonial links \\ either between colonizer and colony or between those countries \\ having been colonized by the same colonizer after 1945, zero \\ otherwise. \\ Border \\ Comlang \\ Dummy which is 1 if the countries share a border, zero otherwise. \\ Bankscope \\ Kaufmann, Kraay and Mastruzzi (2005) \\ Kaufmann, Kraay and Mastruzzi (2005) \\ Dummy which is 1 if the countries share the same language, zero \\ otherwise. \\ Distance The log of the distance between the host and source countries, zero \\ otherwise. \\ Trade \\ Log of export plus import between the source and host countries \\ measured in 2000 \\ LegalDif Dummy which is 1 if the origin of the legal system of host and \\ source country differ, zero otherwise. \\ GDPhost \\ Log of GDP in current US dollars in host country, measured in 2000 \\ FinDepthhost \\ Entryres \\ Log of M2 as percentage of GDP in the host country in 2000. \\ Kaufmann, Kraay and Mastruzzi (2005) \\ and International Financial Statistics \\ CIA World Factbook (2005) \\ CIA World Factbook (2005) \\ CIA World Factbook (2005) \\ CIA World Factbook (2005) \\ UN Comtrade \\ Easterly and Sewadeh (2001) Global \\ Development Network Growth Database \\ and CIA World Factbook (2005) \\ International Financial Statistics \\ International Financial Statistics \\ Dummy which is 1 if foreign bank entry is restricted, zero otherwise. \\ Foreign bank entry is considered restricted when foreign ownership \\ is limited to be less than 50 percent, or when no branches or \\ subsidiaries can be openened, or when only banks from countries \\ that are considered well-supervised can enter the market. Entry \\ restrictions are based on 2005. \\ GDPsource \\ Log of GDP in current US dollars in source country, measured in \\ 2000 \\ GDPcapsource \\ Log of GDP per capita in current international \$ in source country, \\ measured in 2000 \\ Barth, Caprio and Levine (2006) updated \\ with information from several sources \\ International Financial Statistics \\ World Development Indicators
}

